\title{
Correction to: Mixed methods analysis of Health-Related Quality of Life in ambulant individuals affected with RYR1-related myopathies pre-post- $\mathrm{N}$-acetylcysteine therapy
}

\author{
Carlos Capella-Peris $^{1}$ (D) Mary M. Cosgrove ${ }^{1}$ (D) Irene C. Chrismer ${ }^{1}$ (D) Magalie Emile-Backer $^{1} \cdot$ M. Sonia Razaqyar $^{1}$ (D) \\ Jeffrey S. Elliott ${ }^{1} \cdot$ Anna Kuo $^{1} \cdot$ Paul G. Wakim $^{2}$ (D) Katherine G. Meilleur ${ }^{1}$ (D)
}

Published online: 1 April 2020

(c) Springer Nature Switzerland AG 2020

\section{Correction to: Quality of Life Research https://doi.org/10.1007/s11136-020-02428-2}

The article Mixed methods analysis of Health-Related Quality of Life in ambulant individuals affected with RYRl-related myopathies pre-post- $N$-acetylcysteine therapy, written by Carlos Capella-Peris, Mary M. Cosgrove, Irene C. Chrismer, Magalie Emile-Backer, M. Sonia Razaqyar, Jefrey S. Elliott, Anna Kuo, Paul G. Wakim, Katherine G. Meilleur, was originally published electronically on the publisher's internet portal (https://doi.org/10.1007/s11136-020-02428-2) on 10 February 2020 with open access. With the author(s)' decision to step back from Open Choice, the copyright of the article changed on 1 April 2020 to () Springer Nature Switzerland AG, 2020 and the article is forthwith distributed under the terms of copyright.

The original article has been corrected.

Publisher's Note Springer Nature remains neutral with regard to jurisdictional claims in published maps and institutional affiliations.

The original article can be found online at https://doi.org/10.1007/ s11136-020-02428-2.

Carlos Capella-Peris

carlos.capellaperis@mail.nih.gov; capellac@uji.es

1 Neuromuscular Symptoms Unit, Tissue Injury Branch, National Institute of Nursing Research, National Institutes of Health, Bethesda, MD, USA

2 Biostatistics and Clinical Epidemiology Service, National Institutes of Health Clinical Center, Bethesda, MD, USA 